\title{
The inter-play between formal and informal practices
}

\section{Jan van Tatenhove, Jeannette Mak \& Duncan Liefferink}

To cite this article: Jan van Tatenhove, Jeannette Mak \& Duncan Liefferink (2006) The inter-play between formal and informal practices, Perspectives on European Politics and Society, 7:1, 8-24, DOI: $10.1080 / 15705850600839470$

To link to this article: https://doi.org/10.1080/15705850600839470

\section{Published online: 18 Feb 2007.}

Submit your article to this journal $\square$

山ll Article views: 879

Q View related articles $\longleftarrow$

4 Citing articles: 8 View citing articles 


\title{
The Inter-play between Formal and Informal Practices
}

\author{
JAN VAN TATENHOVE*, JEANNETTE MAK** \& \\ DUNCAN LIEFFERINK ${ }^{\dagger}$ \\ *Department of Social Sciences, Environmental Policy, Wageningen University, The Netherlands \\ **Department of Political Science, University of Amsterdam, The Netherlands \\ ${ }^{\dagger}$ Department of Environmental Policy Science, Raboud University, Nijmegan, The Netherlands
}

\begin{abstract}
This article deals with the interaction between formal and informal politics in the $E U$. First of all, it argues that the EU is a special setting for such interaction, as compared to other political systems, as a result of its speedy institutional development and multi-layered nature. Then, it briefly addresses new institutionalist and governance approaches to informality, as well as the strategic motivations behind informal practices. Four such strategies are distinguished. At the co-operative end of the spectrum informal practices may be intended either as a lubricant for applying existing rules or as an experimental garden for trying out new rules. More conflictual strategies may aim at re-directing policy substance or the application of existing rules (critical voice) or rather at circumventing those rules. On that basis, the article presents the 'staging' of practices as a way to understand the interplay of formal and informal practices. Informality can take place in front stage settings where rules are pre-given or in backstage settings where rules are not pre-given, while at the same time these settings can be formally sanctioned or not. Besides formal front stage practices this may result in three types of informal practices: informal front stage practices, formally sanctioned backstage practices and 'sub-politics'.
\end{abstract}

KEY WORDS: European governance, multi-level governance, policy practices, informality

\section{Introduction}

Although informality is by no means a new issue in EU studies, the subject has gained new urgency recently. In this article, we will touch upon some of the general reasons for this renewed attention but the focus is on the interplay between formal and informal practices in the EU. How can informality be defined and classified, and does this need to be done in relation to formality? In order to answer these questions, we start our analysis in the next section by briefly examining the unique character of the EU. We focus on the interconnectedness of inter-governmental, supra-national and trans-national arenas, which make the EU in our opinion a special case for

Correspondence Address: Jan van Tatenhove, Wageningen UR, Department of Social Sciences, Environmental Policy, P.O. Box 8130, 6700 EW Wageningen, The Netherlands.

Email: jan.vantatenhove@wur.nl 
studying the dynamics of formality and informality. In general informality is under theorised in social and political sciences. Exceptions are new institutionalist and governance approaches, in which informality is regarded as a virtue in its own right. Based on these theoretical approaches we then formulate a definition of informality and develop a model to understand the strategies behind the emergence of informal practices in EU policy making. In order to understand the dynamics of formal and informal practices on different levels, we then introduce the staging of practices. The model of staging of practices is based on the dimensions formally sanctioned versus not formally sanctioned (the script of policy making) on the one hand and front stage versus back stage (referring to the positioning of agents in a specific setting) on the other. Beyond formal practices, this will result in three types of informal practices: informal front stage; formally sanctioned back stage and subpolitics. In the penultimate section we address the consequences of changes in the degree and type of formality of practices on the factors openness and accountability of the different stages of EU policy making; the empowerment of the various actors in the system and the basis of such power; and the problem-solving capacity of the EU political system. Finally we draw some conclusions.

\section{The Unique Character of the EU}

Examining the inter-play between formal and informal practices in the framework of the EU implies first of all a thorough understanding of the peculiarities of the EU political system. As is often argued, it finds itself in a grey area somewhere between an international organisation and a fully fledged polity. In our opinion, understanding the nature of the Union, and the role of formality and informality therein, demands an insight in the following three characteristics. Firstly, the EU is in constant flux. Over the years, it has tremendously increased both the number of its Member States and its competencies. As a result, it has moved from a rather technocratic and economic instrument of international co-operation between six countries to an inherent part of domestic political affairs of Member States covering nearly the whole European continent. This has led to unprecedented institutional developments. Also within national systems, to be sure, basic institutions and rules of the game are sometimes changed, but the pace and scope of change in the EU, with sometimes two or three Treaty revisions per decade, is unrivalled. In this dynamic institutional environment, working routines are continuously evolving. Often, these are quickly prescribed in detail in new formal rules. Equally often, however, institutions are slow to adjust to new realities. As a result, there is a vigorous development in both formal and informal practices in the EU, as well as in the relationship between them.

Secondly, the Union is driven by inter-governmental history-making decisions of the heads of governments and states, translated in treaties and treaty changes, as well as by day-to-day politics made by a large number of governmental and nongovernmental actors at several levels. The latter play a major role in interpreting and practising the agreed rules and norms and in implementing decisions. No matter how detailed the treaties may be, they leave ample room for various actors to pragmatically use them in the most effective way or to twist them into their own advantage. The discrepancy between (formal) treaty changes and (informal or 
semi-informal) policy practices, and the fact that there are other actors involved, is highly relevant for the study of informality in the EU.

Finally, the EU is a fragmented system with differentiated competences according to policy area and layer of governance, often formulated in an ad-hoc fashion in response to policy problems. As a result, decision-making rules and policy responsibilities are strongly varying according to the specific situation. In order to keep the system functioning, new and unconventional policy arrangements have been designed, bringing together for example NGOs, scientists, representatives of the Commission, Member States and regions, trying to establish new institutional rules. This in turn has often contributed to both the complexity and the informality of the system.

Considering the EU as in constant flux, fragmented, and balancing between intergovernmental bargaining and multi-level governance, its structure should be understood as the inter-connection of inter-governmental, supra-national and trans-national arenas (van Tatenhove, 2003). Each of these arenas has its own characteristics in terms of participants, policy arrangements and procedures.

In the inter-governmental and supra-national arenas the role of codified institutions such as national governments and EU institutions is dominant. Member States play a prominent role in the European Council and the Council of Ministers. At the same time the supra-national arena, consisting of the European Commission (EC), the European Parliament (EP) and the European Court of Justice (EJC), gained more and more independent influence on collective decision making, involving a significant loss of control for individual national governments (Hooghe \& Marks, 2001).

Besides the inter-governmentalist and supra-national arena, a trans-national arena emerged consisting of a diversity of formal and informal institutions and organisations. Examples of formal trans-national institutions are the diversity of committees and European agencies. With the institutional reforms of the last decades there was a growing need for co-operation between the sub-national, national and supra-national levels, especially concerning the implementation of EU policies. The institutionalisation of a diversity of committee structures in all stages of the policy process gave in to the need to establish fora in which policy ideas could be deliberated upon, policy proposals could be discussed, and policy implementation could be monitored (Christiansen \& Kirchner, 2000). These committees differ with respect to membership (Member State and EU representatives, non-state actors), with respect to their formal position and with respect to their competences. Furthermore, a number of European agencies had been established during the 1990s that deal with regulatory policies, including environmental protection, pharmaceutical regulation, trademark and design registration etc. Keleman (2002) has shown that the growing legislative power of the European Parliament changed the politics of 'Eurocratic' structures; it asserted a more powerful role in the oversight of existing EU executive bodies and in the design of new ones. The agencies, with their information gathering, product-licensing and monitoring tasks, have nowadays a significant influence on regulation in the EU: They improve the Community's monitoring capacity and fulfil regulatory functions in administrative practices outside the Commission's direct control (Kelemen, 2002). Examples of informal trans-national institutions are 'epistemic communities' (Haas, 1992), 'Communities of Practice' (Wenger, 1998), 'best practices' or benchmarking. Communities of Practice $(\mathrm{CoP})$ are informal networks which create many opportunities for participants to 
learn from one another's experiences in policy practices. It is the shared learning and interest of its members what keeps such an informal community together. An example of a $\mathrm{CoP}$ in environmental policy is IMPEL (Implementation and Enforcement of Environmental Law). The control and enforcement of environmental policy is part of a struggle for competences between the Member States and 'Brussels', leaving considerable room for individual mechanisms such as IMPEL. IMPEL is an informal network of environmental civil servants in the Member States concerned with industrial installations, whose objectives are to create necessary impetus for progress on ensuring a more effective application of environmental legislation. By exchanging information and defining best practices (benchmarking), IMPEL seeks to improve the consistency of the implementation, application and enforcement of environmental legislation.

The EU is in constant flux, fragmented and balancing between inter-governmental bargaining and multi-level governance. This makes the EU unique compared to nation-states and international organisations. The continuous inter-relations between inter-governmental, supra-national and trans-national arenas, with their balanced relations between formal and informal practices in policy, make the EU a special case to study the dynamics of formality and informality.

\section{New Institutionalist and Governance Approaches to Informality: Towards a Definition}

Unlike formal aspects of policy making, informality as a concept is not well defined in, for example, organisation theory, sociology or political science. Informality is often described and analysed in relation to or opposite to formality or formal aspects of policy making. In this section, we briefly deal with two approaches that have paid specific attention to informal practices; new institutionalism and governance theory. In both new institutionalism and within governance theory, informality is often regarded as a virtue in its own right. Informal conventions, forms of negotiations and lobbying, policy networks and informal agenda setting are all types of informality that not only allow flexible non-codified forms of interaction by a large and varying number of actors, but these forms of informality co-exist side-by-side formal rules and institutions. According to this rationale, there is an inter-play between formal and informal practices. One could expect that arrangements would become increasingly informal if new practices take place outside and beyond enforceable codes, while at the same time informal practices could institutionalise in formal rules and procedures. Both the history and recent study of European cooperation have shown an ongoing institutionalisation of exchanges and agreements. A closer look at both approaches may shed some light on this dynamic.

\section{Informality in New Institutionalism}

The inter-play between formal rules and procedures and informal rules is central in new institutionalism. Since March and Olson wrote their famous article in 1984, institutions are back in fashion and more important 'institutions matter'. Different strains of new institutionalism have been developed, such as normative, rational choice, historical, empirical, international, sociological and network institutionalism 
(Lowndes, 2002). The core concept in all variants of new institutionalism is 'institution': "a relatively enduring collection of rules and organised practices, embedded in structures of meaning and resources that are relatively invariant in the face of turnover of individuals and relatively resilient to the idiosyncratic preferences and expectations of individuals and changing external circumstances" (March \& Olson, 2005, p. 4). The rules, routines, norms and identities of an 'institution' are the basic units of analysis, rather than micro-rational individuals or macro-social forces (p. 20). Based on an analysis of new institutionalism in several disciplines, Goodin has formulated seven propositions; the core of these propositions is that institutions constrain or enable human agency, while at the end of the day institutions are produced and reproduced in human action (1996, pp. 2-20). In general, new institutionalism is concerned with the informal conventions of political life as well as with formal constitutions and organisational structures (Lowndes, 2002, p. 91). To understand the interplay between formality and informality we do not need to summarise the new institutionalism debate in detail, but we focus on the role of rules in policy making in particular. It is general accepted that rules and rule systems (institutions) range from relatively informal, customary standards of conduct to codified systems of law (Stone Sweet et al., 2001, p. 7). According to Lowndes, the informal rules of political life can be every bit as important in shaping actors' behaviour as formally agreed procedures. Informal conventions may reinforce formal rules, but may also override formal rules or serve to incorporate changes in formal arrangements (pp. 98-99). Since the EU is a political system with such a complex and dynamic institutional set-up, as was pointed out above, it is necessary to briefly elaborate upon the relations between institutions, organisations and actors (cf. Hall \& Taylor, 1996), their degree of formality and the interaction between them. Rule systems (institutions) steer behaviour by organisations or individuals, which in turn can be influenced again as a result of them. It is for example common knowledge in EU studies that treaty changes trigger off informal day-to-day practices, either because the formal rules are unspecific, unworkable or regarded as undesirable. Such practices may be formalised at a next treaty change. The EU is believed to have a large potential for (either anticipated or unforeseen) informal side effects as a result of the resistance of strong EU institutional actors, the institutional obstacles to reform within the EU, and the high costs of policy reversal (Pierson, 1996). Moreover, while competences are delegated to European organisations or agencies, in order to limit transaction costs, to establish commitments to long-term aims or to prevent situations where Member States try to evade agreements, these actors may at the same time use obtained powers to pursue their own preferences. This is more likely to happen in unclear institutional arrangements that leave room, and may even demand, flexible and informal day-to-day politics in order to keep the system running, and where control mechanisms are not (yet) fully in place (Kassim \& Menon, 2003). It has been argued that the consensual decision rules and the heterogeneity of Member State actors in the EU tend to lead to a stalemate in decision making. This deadlock situation may then be overcome by overt (formal) and covert (informal) strategies. An overt way would be the explicit and straightforward specifying and modification of existing formal rules by adjudication and negotiations, while covert ways would be the formation of new informal soft rules, strategies or informal institutions and networks, or more indirect by 
concealing delicate issues in secluded circles, and by fitting issues into a new policy context where the chances of being accepted are greater (Héritier, 2001a).

Stacey and Rittberger (2003) have defined informal institutions in the EU as all rules that lack both a formal foundation - i.e. legally created and ratified by the Member States - and third party legal oversight by the ECJ. These may take any variety of forms, including customs, routines and various ad hoc procedural rules that tend to get created in the course of informal bargaining between the Council, Commission and Parliament outside of standard legislative procedures (p. 879). This is both a wide and a narrow definition, as it includes everything that is not strictly 'legal', yet it is limited to practices that are created by and between interactions between a limited number of highly institutionalised actors. As we are interested in the inter-play between formality and informality at the level of both policy practices and institutions and in interactions between a larger number of players, we borrow equally from governance theory to get to a definition of informal practices in the EU.

\section{Informality in Governance Approaches}

Whereas the rise of the practice and vocabulary of governance is by no means specific for the EU, European politics have proven to be fertile ground. A wide variety of modes of governance have emerged to understand the dynamics of EU politics and policy making. Network governance, committee governance and multilevel governance all reflect new interactions between actors from state, market and civil society. In particular, the concept of multi-level governance is relevant to understand the dynamics of EU policy making, by adding a specific focus on the involvement of various types of actors at different levels. Multi-level governance, in other words, concerns the shifting locus and focus of policy making and the sharing of competencies in a system of negotiation between nested governmental institutions at several levels (supra-national, national, regional and local) on the one hand, and private actors (NGOs, producers, consumers, citizens, scientists etc.) on the other.

According to Castells the EU is a fundamental instrument for the survival of existing nation-states on the condition of conceding shares of sovereignty in exchange for a greater say in the world, and domestic, affairs in the age of globalization' (1998, p. 330).

...the image illustrates powerfully the new form of state epitomised by European institutions: the network state. It is a state characterised by the sharing of authority (that is, in the last resort, the capacity to impose legitimised violence) along a network. A network, by definition, has nodes, not a centre. Nodes may be of different sizes, and may be linked by asymmetrical relationships in the network, so that the network state does not preclude the existence of political inequalities among its members. Indeed, all governmental institutions are not equal in the European network. (Castells, 1998, p. 332, italics in original)

Characteristic for forms of multi-level governance is their ability to grasp the dynamics of (formal and informal) policy making in the EU as the inter-play 
between different actors at different levels. Essentially, formal political (European and Member State) institutions no longer alone exercise a monopoly in the orchestration of governance. Instead, governmental institutions, market parties and civil society representatives share decision-making competencies. This not only entails a decreasing emphasis on central rule making, but also the emergence of more open multi-level policy arrangements, networks and new (trans-national) coalitions of actors, which have the capability to change the rules of the game. Recently, discussions about governance are focusing more and more on society-centred forms of governance. These emphasise the co-ordination and various forms of formal or informal types of public-private interaction based on self-governance (Peters \& Pierre, 2001; Pierre, 2000, p. 3). National governments thus no longer prevail in European policy making (Hooghe \& Marks, 2001, pp. 3-4).

European institutions, sub-national actors as well as private actors play a role of their own and operate in national, supra-national and trans-national arenas. In this sense, policy making in a multi-level governance setting resembles neither traditional international politics, nor policy making in any of the Member States. Obviously, the formal, rule-directed arrangements that provide the official setting of EU politics, i.e. institutionalised inter-relations between European institutions and national governments, formal decision making procedures etc., still play an important role. At the same time, a diversity of more or less informal arrangements constitutes multi-level governance and policy making in the EU. These arrangements range from various types of committees and regulatory agencies to informal networks for the exchange of 'best practices' to improve implementation.

In this sense, multi-level governance shows characteristics of Beck's notion of subpoliticisation, which pre-supposes the inter-mingling of rule-directed and rulealtering politics (Beck, 1994, pp. 34-41; Beck, 1996; Franklin, 1998). Rule-directed politics "can certainly be creative and nonconformist, but it operates within the rule system of industrial and welfare state society in the nation-state... Rule-altering politics, on the other hand, aims at a "politics of politics" in the sense of altering the rules of the game themselves' (Beck, 1994, p. 35). This kind of meta-politics can refer to the switching of the rule system or to the question of what system of rules one should switch to. Paying attention to the inter-mingling of rule-directed and rulealtering practices in EU policy making will put the dominance of representative, ruledirected, governmental institutions in perspective, by calling attention to a whole array of politics taking place outside the formal political institutions (rule-altering politics).

\section{Informality and Informal Strategies}

In an earlier attempt to understand informal governance, Christiansen et al. (2003) have focused on network governance in the EU and given a large number of factors on which these may vary. ${ }^{1}$ Furthermore, they have defined governance as informal when participation in the decision-making process is not yet or cannot be codified and publicly enforced (2006, p. 6). Inspired by new institutionalism and governance approaches we define informal practices as those non-codified settings of day-to-day interaction concerning policy issues, in which the participation of actors, the formation of coalitions, the processes of agenda setting, (preliminary) decision making and 
implementation are not structured by pre-given sets of rules or formal institutions. This definition of informal practices emphasises the 'rules of the game' and the specific way in which rules guide and constrain the behaviour of actors in the inter-play of formal and informal practices.

Informal practices may have come into existence for various reasons, be they accidental, pragmatic, intentional, interest-driven or ideological. However, the specific interplay of informal and formal practices largely depends on the strategic intent of actors participating in those informal practices. We may roughly distinguish two strategic motivations behind the emergence of such practices: one may be labelled co-operative, the other conflictual. Co-operative strategies presuppose a mutual learning relationship between formal and informal practices, while conflictual strategies assume an antagonistic relationship between informal and formal practices. In a second step, both categories can be sub-divided into a variant that operates primarily within the boundaries of existing rules and one that rather seeks to change those rules.

In the 'co-operative' category, we would find strategies that aim at 'greasing the wheel' (Wincott, 2003) or helping to 'escape deadlock' (Héritier, 1999). Actors embedded in formal arrangements and practices may have decided or developed routines to deal with matters in ways that are not (yet) formally approved or accepted. Often, the reason for this is just to facilitate formal processes of agenda setting, decision making or implementation. Here, informal practices act as a lubricant within a given formal setting, without changing the rules of the latter. In other cases, actors may wish to employ the relative freedom provided by a more informal setting for developing alternatives for formal practices. Informal practices then play the role of an experimental garden for new rules, which may well become formalised at a later stage.

In the second category informal practices are developed in opposition to formal ones. Actors initiating or joining these practices are motivated by the wish to change undesirable developments within formal practices. On the one hand, this may be oriented towards the specific substance of policies or the proper application of existing rules. Examples of actors thus raising their critical voice are environmental groups that urge for a more far-reaching climate policy or individuals who reveal to the public eye cases of fraud in EU programmes. On the other hand, actors may be discontented with existing rules and deliberately try to circumvent those rules, not by way of experiment but rather as an escape from formal routes that do not function to their satisfaction. Again, the alternative routes thus created may get formalised at a later stage, but this is not the primary aim.

The four strategies proposed here can be summarised as in Table 1. Their consequences for the relationship between formal and informal practices will be further worked out and illustrated with the help of some examples in the next section.

Table 1. Strategies behind the emergence of informal practices

\begin{tabular}{lll}
\hline Strategies & Co-operative & Conflictual \\
\hline Rule-directed (pre-given rules) & 1. Lubricant & 2. Critical voice \\
Rule-altering (no pre-given rules) & 3. Experimental garden & 4. Circumvention \\
\hline
\end{tabular}




\section{Staging of Practices}

In order to grasp the dynamics of formal and informal practices on different levels of European policy making, we make use of Goffman's (1959) distinction between front stage and back stage. In his dramaturgical approach, Goffman compares life with a theatre, because performances are necessary if there is to be clear, consistent and recognisable social reality. 'Situations do not simply define themselves: They must be constructed by symbolic communication; and hence social life must be expressive, whatever else it may be' (Collins \& Makowsky, 1998, p. 251). In Goffman's theatrical model of social behaviour, behaviour has an expressive as well as a practical element. Translated to politics, political behaviour is designed to communicate a definition of the political and polity reality as much as to carry out tasks, varying from agenda setting to the implementation and enforcement of politics. In Goffman's view the social world is divided up into front-stage and back-stage regions. 'Front stage' is the place where roles are performed before an audience and where a group project is the optimal definition of the group's situation. In 'back-stage' regions players are freed from the requirements of a particular role; the performers can let down their standards and relax under the cover of a carefully guarded privacy.

Translated to politics and policy we conceptualise 'front-stage politics' as policymaking processes in rule-directed arrangements. In these arrangements (European) governance refers to 'governing' as the inter-play primarily between EU institutions and member-state institutions, but also private actors at various levels may be involved. The Treaties provide the basic set of rules for the functioning of these institutions, the inter-relations between them, the formal decision-making procedures and the competencies of the actors involved. These codified rules are complemented by a wide variety of rules that are also generally accepted, but have not been formally laid down. It is important to note that even at the front stage, these arrangements are not fixed. Given the unique and evolving nature of the EU, the institutional front-stage setting is almost permanently subject to revision.

'Back-stage politics', on the other hand, is the setting in which the roles of actors and the rules of the game are not given beforehand, nor structured by the rules and norms of existing institutions. Back stage is concerned with (rule-altering) arrangements evolving 'on the ground', in the daily interaction between actors from state, market and civil society, each bringing with them their own rationalities of legitimacy, effectiveness and efficiency (van Tatenhove et al., 2000). This is not to say that rule-directed institutions no longer form important contexts for action, but much political and policy-making action either takes place next to or across such orders, or is explicitly meant to establish new institutional rules (cf. Hajer, 2003). In these back-stage (rule-altering) arrangements the rules are inherently less clear, as inter-relations between the actors and their competencies are recursively defined and constructed in interactions. Because actors in these back-stage settings define their own rules and ways to deal with problems, trust is crucial and can result in strong (informal) bonds between the participants in a back-stage arrangement. Eventually, practices developed back stage may trickle down to the front stage and end up as codified rules.

Our perspective on European governance, as a specific form of multi-level governance, emphasises the dynamic inter-play between front stage and back stage, 
in which actors explore the 'borders' of what may be called an institutional void. The absence of 'clear rules and norms according to which politics is to be conducted and policy measures are to be agreed upon' (Hajer, 2003, p. 175) give actors the opportunity to shape and re-shape the rules of the game. As pointed out above, actors may have different motivations to do so. The relationship between front stage and back stage works in both directions. On the one hand, neither the form nor the significance of back-stage practices can be properly understood without taking into account the institutional setting 'behind' which it takes place. On the other hand, back-stage practices are very likely to have effects on the play performed on the front stage. For instance, even co-operative strategies of actors within a rule-directed setting may be affected by processes back stage, but it is also conceivable that new working routines developed back stage 'feed back' in one way or another into more rule-directed policy arrangements.

We have defined informal practices above as those non-codified settings of day-today interaction concerning policy issues, in which the participation of actors, the formation of coalitions, the processes of agenda setting, (preliminary) decision making and implementation are not structured by pre-given sets of rules or formal institutions. Central in this definition are (a) non-codified settings and (b) the fact the rules are not pre-given. However, these two aspects are not identical and we have to make an analytical distinction between them. This provides us with another $2 \times 2$ matrix as presented in Table 2. In order to emphasise the relationship between strategies and settings, the strategic motivations proposed above (Table 1) have been inserted in the figure in bullet points. The vertical axis addresses whether practices are taking place in a front-stage setting where rules are pre-given (i.e. leading to rule-directed behaviour) or in a setting where rules are not pre-given (i.e. leading to rule-altering behaviour). The horizontal axis deals with the question if those setting are codified or not. As will turn out, however, especially in relation to cell 3 , it is in fact more appropriate to speak about settings which are either formally sanctioned or not.

Only cell 1 represents a classical type of formal practice, based on formally sanctioned and codified rules and procedures, for instance those laid down in the EU Treaties. Cells $2-4$ are different kinds of informal practices, because they are either not formally sanctioned, or there are no pre-given rules, or both.

Cell 2 consists of practices that are not formally sanctioned, i.e. not laid down in formal procedures. They are still front stage, however, since policy making and decision making in these practices are based on rules that are commonly agreed upon and accepted by the actors involved. Their informality, in other words, lies in the fact that they are based on rules that are not formally codified and sanctioned. Examples

Table 2. The staging of practices: Formal and informal settings in EU politics

\begin{tabular}{llc}
\hline Settings & Formally sanctioned & Not formally sanctioned \\
\hline $\begin{array}{c}\text { Front stage (rule-directed; } \\
\text { pre-given rules) }\end{array}$ & 1. Formal front stage & $\begin{array}{c}\text { 2. Informal front stage } \\
\bullet \text { lubricant } \\
\text { critical voice }\end{array}$ \\
$\begin{array}{c}\text { Back stage (rule-altering; } \\
\text { no pre-given rules) }\end{array}$ & $\begin{array}{c}\text { 3. Formally sanctioned backstage } \\
\bullet \text { experimental garden }\end{array}$ & $\begin{array}{l}\text { 4. 'Sub-politics' } \\
\bullet \text { circumvention }\end{array}$ \\
\hline
\end{tabular}

Corresponding strategic motivations (see Table 1) have been added (bullet points). 
of such informal practices are various forms of epistemic communities, lobbying and whistle blowing based on the strategies referred to above as 'lubricant' and 'critical voice' (see the next section). In a given political process, both strategies may well be imagined to appear simultaneously as the extremes of a continuum, with some actors (e.g. technical or scientific experts), primarily acting as 'lubricant' and others (e.g. NGOs), raising a more 'critical voice'. It must be noted, furthermore, that such non-sanctioned front-stage practices can be equally disruptive for the formal process as truly rule-altering back-stage practices. A fine example is provided by the case of the Mühlenberger Loch, a wetland of international status close to the city of Hamburg in Germany (Breuer, 2002). In the 1990s, the area came to be threatened by the planned extension of a local Airbus production facility. Environmental groups launched a protest campaign arguing, among other things, that the plan constituted a violation of the EU's Birds and the Habitats Directives. The Commission accepted the complaint in 1999 but any formal action against Germany was stopped short by a letter from the German Federal Chancellor, Gerhard Schröder, to the President of the Commission, Romano Prodi. It successfully claimed that the Airbus project was of utmost economic importance and that no feasible alternative existed. Consequently, an exemption from the relevant provisions was granted to Germany. The Schröder letter is a clear-cut example of an informal strategy making use of existing, de facto hierarchical relations inside the EU. In particular, it exploited the ambiguous position of the President of the Commission. Formally, he is equal to the other Commissioners, but in practice, particularly since the days of Jacques Delors, he acts as a primus inter pares. A good argument put forward to him by the political leader of the biggest EU Member State, even if it cuts across ongoing procedures, has a special power. There was no institutional void involved here, nor did Schröder's 'critical voice' alter any existing rules. It only exploited the existing, unwritten rules of interaction in Brussels.

Cell 3 consists of formally sanctioned back-stage practices, which may at first glance seem paradoxical. What is meant here, however, are practices that have been initiated and authorised by formal institutions, such as the Council or the Commission, but at the same time have a 'rule-altering' nature. In other words, rules are not pre-given - and thus cannot logically be codified - but the setting as such has a formal foundation. This kind of informal practices is characteristic for EU policy-making processes. Because of its rapidly evolving front stage institutional setting, the formal EU institutions intentionally are looking for institutional voids to make policy. ${ }^{2}$ Examples of these informal practices, based on the strategy of the 'experimental garden', are the Open Method of Co-ordination, the Auto-Oil I Programme and some of the 'comitology' committees. The Auto Oil I Programme was an attempt by the Commission, and its DG Environment in particular, to decide on cost-effective measures against air pollution from motor vehicles by negotiating with the car and oil industry directly (Wurzel, 2002). Thus excluding key institutional parties such as the Council (i.e. the Member States) and the Parliament, Auto-Oil was deliberately staged outside the existing institutions. At the same time, it was implemented under the full responsibility of the Commission, rendering it a typical example of a formally sanctioned back-stage process. Along those lines, an agreement between the Commission and industry was reached in 1996. In a second, 
front-stage phase, however, this agreement had to be transformed into formal legislation. At that point, interestingly, the Council and the Parliament to a large extent re-claimed their powers by pushing through far-going changes and amendments to the original agreement. This may be taken as an indication that formally sanctioned 'experiments' at the back stage, and probably institutional voids in general, remain ultimately defined by institutionalised boundaries, not unlike a hole in the cheese that only exists in relation to the cheese surrounding it.

Cell 4, finally, consists of informal practices which are both back stage (i.e. no pregiven rules) and without formal basis, which comes close to Beck's concept of subpolitics. The corresponding strategic motivation is that of 'circumvention', where actors deliberately seek alternative routes outside and beyond existing rules and institutions. A possible example is the way the 14 Member States and the European Commission reacted to the formation and installation of the Austrian government of Chancellor Wolfgang Schüssel, consisting of Schüssel's own Christian-conservative People's Party (ÖVP) and the ultra-right wing Freedom Party (FPÖ) of Jörg Haider, in February 2000. Initially the Commission - referring to Articles 6 and 7 of the Amsterdam Treaty - threatened to take steps if the FPÖ became one of the coalition parties. However, President Prodi of the European Commission was trapped between the principle that the EC does not interfere in domestic developments within an individual Member State and the pressure of the other European leaders to boycott Austria. This case illustrates the existence of an institutional void between the Commission and the European Council. The reaction of the leaders of the 14 Member States were based on national rather than European interests. The result was a 14-fold bilateral boycott against Austria, initiated by the Portuguese Presidency of the Union, the Belgian Prime Minister and the French President. The position of the European Parliament and the European Commission, which in principle have a central role in sanctions against Member States, was undermined. For the following reasons this case may be taken as an example of sub-politics. First, since the Treaty gives no clear rules of how to act in such a situation, the boycott had a back-stage character. Member States used this institutional void to boycott Austria bilaterally. Second, the 14 organised their action outside the formally sanctioned communitarian framework.

It must be noted, however, that examples of genuine sub-politics at the $E U$ level are generally quite hard to find. In many cases, there is at least an element of formal - or at least political - sanctioning involved. At first sight the 'Schengen' agreement on border controls, concluded by a larger group of Member States outside the formal EU framework, is also an example of 'circumvention' of existing rules. But at a closer look the Schengen agreement may also be regarded as an 'experimental garden' for a more differentiated mode of European integration. After all, the EU is at the fairly formalised top of the multi-level pyramid, whereas 'true' sub-politics in Beck's sense take place - or at least start - almost by definition at the bottom of that pyramid.

We consider policy making in a setting of multi-level governance as the outcome of a 'staging of practices'. This staging of practices is the result of the interplay of formal and informal practices, varying on the dimensions formally sanctioned versus not formally sanctioned, and front stage versus back stage. Making use of the metaphor of a theatrical performance, the dimension formally sanctioned versus not 
formally sanctioned refers to the question whether practices are based on some sort of script, while the dimension front stage versus back stage refers to the positioning of actors and coalitions and by that their ability to change the rules of the game or to mobilise resources.

To conclude, the specific 'staging of practices' in different policy domains and the 'institutional voids' characterising the inter-play of formal and informal practices are of course by no means unique for the EU. In every political system, actors continuously explore and trespass the boundaries of formal rules and institutions. However, the particularly dynamic institutional 'environment' of the EU and the types of institutional void that go along with this dynamic context offer exceptional opportunities for 'new' non-hierarchical, public/private policy arrangements to develop at the back stage and, in turn, to alter the rules at the front stage.

\section{Consequences of a Shifting Balance between Formal and Informal Practices for EU Policy Making}

The shifting balance between formal and informal practices in EU policy making undoubtedly is a fascinating theme from an academic point of view but it may also have important consequences for EU policy making in a more practical and normative sense, for instance in terms of the legitimacy or the effectiveness of policies. When studying these consequences, one has to take into account the variety of structural properties of the policy fields covered by the EU. For example, regulatory policies may at the end of the day have to be front stage and formally sanctioned in order to be legitimate. However, the daily functioning of (often highly specialised) areas of regulatory policy may be dependent on flexible interactions with a large range of actors, which cannot always be formally sanctioned. For (re-)distributive and particularly normative issues, in contrast, procedural qualities may be slightly less crucial as they may be judged more on the basis of their outcomes.

Notwithstanding these complications, this section will try to give an impression of the possible effects of changes in degree and type of formality of practices on the following factors: the openness and accountability of the different stages of the decision-making process in the EU; the empowerment of the various actors in the system and the basis of such power; and finally the problem-solving capacity of the EU political system. These aspects reflect the traditional dilemma between input and output legitimacy, i.e. how to increase effectiveness without limiting participation and popular consent, as well as the issue of throughput legitimacy, i.e. the transparency and accountability of procedures. Yet, rather than being outdated, these matters of European governance become an ever more pressing issue, given the complicated relations of co-ordination and authority between the now 25 Member States and the supra-national actors in the EU. This is particularly so in view of the serious legitimacy crisis presently facing the EU and requiring even better coordination, both horizontally across policy sectors and vertically between the EU and its Member States (Schout \& Jordan, 2005). Elaborating on the metaphor of theatrical performance, we can first of all deepen our understanding of the inter-play of formal and informal practices and the consequences for openness (both in term of access and information), accountability and transparency of the different stages of the decision-making process in the EU. In formal front-stage practices both 
interactions and the role of actors in policy making are determined by the pre-given rules (the 'script') of the rule-directed arrangement. Even though in non-sanctioned front-stage practices politics takes place within rule-directed arrangements (i.e. generally accepted rules), actors have room for manoeuvre because not all rules are formally laid down. In formally sanctioned backstage practices a script structures the conduct of actors, but this script allows for (and is in fact often deliberately oriented towards) exploring and possibly changing the institutional borders of the front stage. In non-sanctioned back-stage practices actors, so to say, improvise their own script in day-to-day policy making detached for the time being from the frontstage rules. In each of these settings, the question of inclusion and exclusion is differently framed. In formal front stage practices the participation of actors is clearly defined by participation rules incorporated in decision-making procedures. In both informal front-stage practices and formally sanctioned back-stage practices the participation of actors may for example be based on their (scientific) expertise or specific skills (in the case of lobbying). The difference between the two, in terms of inclusion and exclusion, is connected with the different strategies actors use in these practices. While informal front-stage practices may have a fairly loose (and by definition informal) relationship with formal ones (aimed at formulating alternative goals or to 'correct' undesired developments), the relationship of formally sanctioned back-stage practices and formal practices is based on mutual inter-dependence (for instance because EU institutions have initiated these back-stage practices to make the system work better). This means that in informal front-stage practices, participation is negotiated between the members of these practices, while in formally sanctioned back-stage practices the question of "who is in and who is out" is at least partly defined by members of formal practices. Finally, in non-sanctioned backstage practices membership is negotiated bottom-up, independent of participation rules set in other formal and informal practices. This makes these practices by definition less open, transparent and accountable. However, having drawn this general picture, it must be added that co-operation structures that are characterised by interdependence and based on mutual learning depend by definition on the availability of information and the willingness of the participants to share knowledge. In many cases, moreover, the media can be used as an instrument for peer pressure, as is the practice of naming and shaming. These are all factors that would contribute to openness, transparency and accountability. In this sense, particularly, 'critical voice' strategies could add to these qualities.

With regard to the empowerment of the various actors in the system and the basis of such power we can make the following general observations. An increase in informal practices would be likely to undermine the positions of traditional institutions of representation such as the national parliaments and the EP, as well as the institutions of control and enforcement, such as national courts and the ECJ. At the same time, non-state actors would arguably win from informality as they gain access to decision making and to instruments that were previously privileged to state actors. However, matters may be less simple, as the basis of power may have changed and varies by practice and policy field. Open power play and traditional aspects of authority, such as material resources, size or membership, may have been replaced by expertise, credibility and the ability to convince (de la Porte \& Pochet, 2002). Actors who possess these qualities may be specialised agencies and scientific 
institutions but also personalities with charismatic characteristics or a wide (personal) network; they can equally well be either traditional or new actors in the field. Much then depends on how effective they are in strategically using their resources. Traditionally "weak" actors may either gain as a result of these dynamics, or lose out as they are no longer protected by formal institutions of control and enforcement. More definitive statements can only be made on the basis of further empirical research.

The problem-solving capacity of the EU political system is finally affected in several ways. Informal front-stage strategies as 'lubricant' are clearly meant to increase effectiveness, whereas formally sanctioned back-stage arrangements in the category of 'experimental garden' are prone to lacking well-established mechanisms of enforcement and may thus decrease effectiveness. Non-sanctioned informal practices ('circumvention') could arguably decrease effectiveness in the short run but might actually add to effectiveness in the long run. The 'critical voice' type of informal front-stage practices, finally, could both be detrimental and beneficial to the problem-solving capacity of the EU; very much dependent on the issue at stake. No generalisations can be made here; again only well-structured empirical research might add better insight. While the contributions of this special issue largely give a better understanding of the consequences of the inter-play of formal and informal practices, we hereby nevertheless call for more efforts in that direction.

\section{Conclusions}

In this article we have focused on the inter-play of formal and informal practices in EU policy making. Informality is by no way a new phenomenon. Both in day-to-day policy making and in policy analysis, attention has been paid to issues of informality and the inter-play of informal and formal practices. In EU policy making civil servants of for example the Commission have to deal on a daily basis with lobbyist, scientists and representatives of industry. Given the unique character of the EU, inter-connecting inter-governmental, supra-national and trans-national arenas, informality is a common aspect of everyday working routines. Also in policy analysis as a social science, informality gained new urgency. To understand the changing social and institutional context of policy, new answers had to be found about the way agents negotiate the rules and the emergence of new political spaces and structures of governance. Especially governance approaches and strains of new institutionalism address these questions and thus provide the tools for understanding informality.

In this article we step-wise developed a model to understand the dynamics of formal and informal practices in EU policy making. We started with a definition of informal practices, emphasising the 'rules of the game' and the way those rules constrain and guide the behaviour of the actors involved. We then distinguished two basic types of strategic motivation of agents participating in informal practices (cooperative vs. conflictual) and confronted those with the extent to which agents seek to change the existing rules (rule directed vs. rule altering). Thus, we distinguished four ideal-typical strategies: lubricant, experimental garden, critical voice and circumvention. The second step in our analysis concerned the staging of practices. Beyond formal, rule-directed practices, this resulted in three types of informal 
practices: informal front stage; formally sanctioned back stage and sub-politics, with their corresponding strategies.

With the staging of practices we contribute to the debate on multi-level governance. Whereas 'classical' accounts of multi-level governance tend to focus on evolving formal relationships between actors at different levels, we believe that the inter-play of formal and informal practices may help to better understand the forces behind the multi-level dynamic. Thus, our analysis constitutes an enrichment (rather than a criticism) of more descriptive approaches of multi-level governance on the one hand and those approaches focusing on the inter-play between the intergovernmental and supra-national arena on the other. The staging of practices, moreover, may provide a starting point for evaluating the inter-play between formal and informal practices in a more normative sense, for instance in terms of the openness and accountability, the empowerment of involved agents and the problemsolving capacity of EU policy making. Particularly when it comes to those issues, however, many more factors tend to be at play as well and more empirical research would be needed to substantiate the general claims made in this paper.

\section{Notes}

${ }^{1}$ Networks can be private or public, overt or covert, short or long term, stable or fluid, single or multi level, based on an individualist or a collectivist ethos, rationality or value oriented, assist integration or favour fragmentation, engender convergence or divergence and seek to exert general influence or pursue specific policy outcomes (Christiansen et al., 2003).

2 Compare Héritier's 'covert' practices and subterfuge (2001a, 2001b).

\section{References}

Beck, U. (1994) The reinvention of politics: Towards a theory of reflexive modernization, in: U. Beck, A. Giddens \& S. Lash (Eds) Reflexive Modernization: Politics, Tradition and Aesthetics in the Modern Social Order, pp. 1-55 (Oxford, UK: Polity Press).

Beck, U. (1996) World risk society as cosmopolitan society? Ecological questions in a framework of manufactured uncertainties, Theory, Culture \& Society, 13(4), pp. 1-32.

Breuer, F. H. (2002) Multi-level governance, the new approach and the implementation of EU environmental policies, MA Thesis, University of Amsterdam.

Castells, M. (1998) End of Millennium (Oxford, UK: Blackwell).

Christiansen, T., Føllesdal, A., \& Piattoni, S. (2003) Informal governance in the European Union: An introduction, in: T. Christiansen \& S. Piattoni (Eds) Informal Governance in the European Union, pp. 1-21 (Cheltenham, UK: Edward Elgar Publishing Limited).

Christiansen, T., \& Kirchner, E. (Eds) (2000) Committee Governance in the European Union (Manchester: Manchester University Press).

Collins, R., \& Makowsky, M. (1998) The Discovery of Society (6th ed.) (Boston: McGraw-Hill).

De la Porte, C., \& Pochet P. (Eds) (2002) Building Social Europe Through the Open Method of Co-ordination (Brussels: P. I. E. Peter Lang).

Franklin, J. (Ed.) (1998) Politics of Risk Society (Cambridge, UK: Polity Press).

Goffman, E. (1959) The Presentation of Self in Everyday Life (New York: Doubleday).

Goodin, R. E. (1996) Institutions and their design, in: R. E. Goodin (Ed.) The Theory of Institutional Design, pp. 1-53 (Cambridge, UK: Cambridge University Press).

Haas, P. M. (1992) Introduction: Epistemic communities and international policy coordination, International Organization, 46(1), pp. 1-35.

Hajer, M. (2003) Policy without polity? Policy analysis and the institutional void, Policy Sciences, 36(2), pp. $175-195$. 


\section{J. van Tatenhove et al.}

Hall, P. A., \& Taylor, R. C. R. (June 1996) Political science and the three new institutionalisms, MPIFG Discussion Paper No. 96/6.

Héritier, A. (1999) Policy-making and Diversity in Europe (Cambridge, UK: Cambridge University Press). Héritier, A. (2001a) Overt and covert institutionalization in Europe, in: A. Stone Sweet, W. Sandholtz \& N. Fligstein (Eds) The Institutionalization of Europe, pp. 56-70 (Oxford, UK: Oxford University Press).

Héritier, A. (2001b) Policy-making by subterfuge: Interest accommodation, innovation and substitute democratic legitimation in Europe - perspectives from distinctive policy areas, Journal of European Public Policy, 4(2), pp. $171-189$.

Hooghe, L., \& Marks, G. (2001) Multi-Level Governance and European Integration (Lanham: Rowman \& Littlefield Publishers).

Kassim, H., \& Menon, A. (2003) The principal-agent approach and the study of the European Union: Promise unfulfilled? Journal of European Public Policy, 10(1), pp. 121 - 139.

Kelemen, R. D. (2002) The politics of 'Eurocratic' structure and the new European agencies, West European Politics, 25(4), pp. $93-118$.

Lowndes, V. (2002) Institutionalism, in: D. Marsh \& G. Stoker (Eds) Theory and Methods in Political Science, pp. 94-97 (Basingstoke, UK: Palgrave Macmillan).

March, J. G., \& Olsen, J. P. (1984) The new institutionalism: Organizational factors in political life, American Political Science Review, 78(3), pp. 734-749.

March, J. G., \& Olson, J. P. (2005) Elaborating the 'New Institutionalism', Working Paper No. 11 (Oslo: Centre for European Studies, University of Oslo).

Peters, B. G., \& Pierre, J. (2001) Developments in intergovernmental relations: Towards multi-level governance, Policy and Politics, 29(2), pp. 131-135.

Pierre, J. (Ed.) (2000) Debating Governance. Authority, Steering and Democracy (Oxford, UK: Oxford University Press), p. 3.

Pierson, P. (1996) The path to European integration, A historical institutionalist analysis, Comparative Political Studies, 29(2), pp. $123-163$.

Schout, A., \& Jordan, A. (2005) Coordinated European governance: Self-organizing or centrally steered?, Public Administration, 83(1), pp. 201-220.

Stacey, J., \& Rittberger B. (2003) Dynamics of formal and informal institutional change in the EU, Journal of European Public Policy, 10(6), pp. 858-883.

Stone Sweet, A., Sandholtz, W., \& Fligstein, N. (Eds) (2001) The Institutionalization of Europe (Oxford, UK: Oxford University Press).

Van Tatenhove, J. (2003, 28 March-2 April) Multi-level governance and the 'institutional void': The interplay between frontstage and backstage politics. Paper presented at workshop 21, ECPR Joint Sessions.

Van Tatenhove, J., Arts, B., \& Leroy, P. (Eds) (2000) Political Modernisation and the Environment: The renewal of environmental policy arrangements (Dordrecht/Boston/London: Kluwer Academic Publishers).

Wenger, E. (1998, June) Communities of practice: Learning as a social system, Systems Thinker, 9(5), pp. $1-10$.

Wincott, D. (2003) Backing into the future? Informality and the proliferation of governance modes (and policy participants) in the EU, in: T. Christiansen \& S. Piattoni (Eds) Informal Governance in the European Union, pp. 226-236 (Cheltenham: Edward Elgar Publishing Limited).

Wurzel, R. K. W. (2002) Environmental Policy-making in Britain, Germany and the European Union: The Europeanisation of Air and Water Pollution Control (Manchester/New York: Manchester University Press). 